\title{
The Role of Consumers' Individual Differences and Perceived Product Quality in Sustainable Luxury Marketing: An Experimental Study in a Social Media Context
}

\author{
Giuseppe Colella ${ }^{1}$, Andrea Sestino $^{1} \&$ Cesare Amatulli ${ }^{1}$ \\ ${ }^{1}$ Ionian Department in "Mediterranean Legal and Economic Systems: Society, Environment, Culture", University \\ of Bari “Aldo Moro", Via Duomo, 259, 74123 Taranto, Italy \\ Correspondence: Giuseppe Colella, Ionian Department in "Mediterranean Legal and Economic Systems: Society, \\ Environment, Culture", University of Bari “Aldo Moro", Via Duomo, 259, 74123 Taranto, Italy.
}

Received: January 6, 2022

Accepted: February 21, 2022

Online Published: February 27, 2022

doi:10.5539/ijms.v14n1p34

URL: https://doi.org/10.5539/ijms.v14n1p34

\begin{abstract}
Sustainability has become a central issue for luxury marketers and managers. By considering the luxury sector, consumers are more interested in buying sustainable products. However, luxury brands need to find the right way to communicate their sustainable products, especially in the online context. This paper sheds light on the differentiated effect of a luxury product communication message focused on an internalized versus externalized luxury approach in social media platforms context. Internalized luxury refers to luxury consumption mainly driven by individual style, while externalized luxury consumption refers to luxury consumption mainly driven by status. Results show that a sustainable luxury product communication focused on internalized (vs. externalized) luxury activates a greater perception of product quality, which in turn leads to a greater intention to buy. Theoretical contributions and implications for luxury brand managers are discussed.
\end{abstract}

Keywords: luxury products, product quality, social media, digital marketing, sustainability

\section{Introduction}

The boom in the luxury sector and its growing economic relevance has prompted scholars, academics, and managers to explore the concept of luxury, investigating the dimensions of luxury and identifying the drivers of luxury consumption (Atwal \& Williams, 2017; Dubois et al., 2020). However, despite the interest of scholars in the study of luxury consumption, there is not a universal definition of luxury yet (Belk, 1999; Mundel et al., 2017). Pantano et al. (2018) sustained that luxury represents people leading an exclusive and inaccessible lifestyle dominated by wealth and consumption is driven by social attributes such as self-expression and the need to exhibit social standing. Furthermore, Nia and Lynne Zaichkowsky (2000), highlighted that luxury is a state of prestige and the possession of a luxury item is not associated with a functional utility. The construct of luxury is linked to different aspects such as sensual experiences and premium price (Kapferer, 1997), but not to production costs (Nueno \& Quelch, 1998), and luxury product-related characteristics in terms of quality, uniqueness, and rarity (Roux; 1991; Vigneron \& Johnson, 2004). Although the concept of luxury still presents a certain non-univocity, the literature on the luxury brand has intended to outline specific characteristics associated with it (Ko et al., 2019; Maman Larraufie \& Kourdoughli, 2014; Roux; 1991; Sung et al., 2015; Vigneron \& Johnson, 2004). In this context, the literature stresses that a single definition of luxury products must include six fundamental characteristics that is authenticity, quality, premium price, resonance, visibility and prestige (as in Godey et al., 2016; Colella et al., 2019). Hudders et al. (2013) pointed out that luxury brands are represented by a mix of characteristics such as exclusivity, uniqueness, scarcity, premium price, great quality and aesthetics. Importantly, by offering premium products, luxury brands tend to arouse pleasure for consumers at an emotional level (Hagtveded \& Patrick, 2009). Moreover, from the literature it emerges that quality is a key characteristic of luxury brands (Keller, 2009; Ko et al., 2019; Okonkwo, 2007). The recent economic growth has coincided with a mounting commitment toward sustainable development among luxury brands (Kadam \& Deshmukh, 2019). Despite the relevance of sustainability for luxury brands and consumers, research mainly investigated sustainable consumption in the context of mass-market products and brands (Lunde, 2018). In particular, to the best of the authors' knowledge, there is a lack of insights about what kind of communication-related to sustainable luxury products is more effective and what is the underlying process. Indeed, today, marketers and managers are 
increasingly committed to communicating sustainability with the aim of building and consolidating their image, trust, and reputation towards the brand and their products (Park \& Kim, 2016). In this sense, the growing concern for environmental issues is urging companies to implement different marketing practices that focus primarily on sustainability (Kotler, 2011).

By considering the increased online presence of many brands today, pro-environmental initiatives aimed to lead sustainable consumption could be conveyed through digital tools reaching more effectiveness (Reilly \& Weiru, 2012; Reilly \& Hynan, 2014), also by leveraging on consumers' consumption for environmentally friendly products in the attempt to show other their "green" status (Griskevicius et al., 2010; Sestino et al., 2021). Among the wide range of digital tools, nowadays, social media may leverage on social interaction to create, distribute and support individuals' consumption though a deeper content creation strategies, to favour consumers' positive attitutes toward their products (Lee et al., 2018; Tsai \& Men, 2013), e.g., by communicating their products as more sustainable rather the other (Reilly \& Hynan, 2014), and exploiting online data to stimulate certain consumption behaviours (Sestino \& De Mauro, 2021). Accordingly, Kaplan and Haenlein (2010, p. 61) define social media platforms as "a group of Internet-based applications that are based on the ideological and technological foundations of Web 2.0, enabling the creation and exchange of user-generated content". In this sense, social media play an important role in the implementation of global communication strategies of companies (Castronovo \& Huang, 2012). According to Obar and Wildman (2015), user-generated content on social media platforms is the lifeblood of online communication, as it allows to connect and reach more people in their social communities and could thus be one of the main communication vehicles of content related to a luxury brand (Godey et al., 2016). Thus, we would shed light on the effect of sustainable luxury product communication focus on consumers' intention to buy, by revealing the mediating role of perceived quality. An experimental study has been carried out by using as a setting a page of a fictitious brand on the social network Instagram due to its current popularity subclassing other ones such as Facebook, Tok-tok or Twitter (Mediakix, 2021) to share visual contents and advertising posts, manipulating the type of communications to investigate consumers' sustainable consumption choices, and the effect of consumers' perceived product quality. Results show that the type of communication focus (internalized vs. externalized luxury) influences the perceived quality of the communicated product, which in turn has an effect on consumers' intention to buy. Thus, we firstly contribute to luxury research and practices by shedding light on how the luxury communication focus may influence consumers' sustainable consumption. Secondarily, we contribute to the literature about sustainable consumption increasing knowledge on how luxury products are becoming consistent with sustainable concepts and pro-environmental behaviors. Thirdly, we contribute to the literature about social media marketing by revealing how social media may be useful in proposing luxury communications with different focus stimulating sustainable consumption behaviours. Lastly, this research contributes to the literature on luxury values. Finally, managerial implications and future research lines will be provided.

\section{Theoretical Framework}

\subsection{Luxury Consumption: Internalized Versus Externalized Motivations}

Traditionally, the consumption of luxury products is based on several factors, such as conspicuous consumption (Chaudhuri et al., 2011; Veblen, 1899), hedonism (Vigneron \& Johnson, 1999), quality, uniqueness and durability (Sheth et al., 1991). On this basis, it is essential to consider the different facets relating to the behavior and motivations of luxury consumption. In this context, the literature on luxury marketing has consolidated the theory of self-determination theory as the basis of studies relating to the behavior and motivations of luxury consumption (Shao et al., 2019; Truong \& McColl, 2011). According to Ryan and Deci (2000), the self-determination theory tends to conform to an approach on the motivations of consumption that focuses on behavior and personality development in social contexts (Truong \& McColl, 2011). In this framework, motivational models that consider both social and individual factors can be considered (Colella et al., 2019; Vigneron \& Johnson, 1999). With reference to motivational models based on social factors, in luxury consumption the importance of the perception that others have of the consumer is considered (Truong \& McColl, 2011), which mainly signals one's wealth and status (Veblen, 1899). If we consider motivational models based on individual factors, however, in luxury consumption we consider the importance of the goals of self-fulfilment and individual style (Tsai, 2005). However, individual factors also include factors such as hedonism and experiential consumption (Müller-Stewens \& Berghaus, 2014). On this basis, the most recent literature on luxury consumption has identified different approaches to luxury consumption, anchoring itself to the relationship between internal and external motivations (Eastman \& Eastman, 2015; O’Cass \& McEwen, 2004). In particular, Amatulli and Guido (2012) have underlined the luxury consumption dichotomy of externalized versus internalized luxury (Guido et al., 2020). Externalized luxury consumption has its roots in the theory of 
conspicuous consumption (Veblen, 1899). In this sense, the consumption of luxury goods relies on the constructs of materialism and ostentation (Belk, 1985; Richins \& Dawson, 1992) and is aimed at indicating status and a social position to others (Guido et al., 2020; Amatulli \& Guido, 2011, 2012; Mason, 2001). On the other hand, internalized luxury consumption, bases its motivations on the more intrinsic side of consumers who are motivated by wanting to experience intimate motivations (Guido et al., 2020) and characterized by a low need for status (Han et al., 2010). In particular, in the context of internalized luxury consumption, consumers find personal satisfaction in the perceived product quality (Dubois et al., 2001; Truong \& McColl, 2011). Therefore, internalized luxury consumption is rooted in personal and intrinsic motivations, such as expressing inner values, tastes, qualities, and individual style (De Angelis al., 2020).

\subsection{Social Media Communication in Sustaining Luxury Type of Communication}

Social media are online platforms useful to connect people to each other sharing ties, from casual knowledge, to working relationships, to family ties (Jiang et al., 2019). The procedures for accessing the social network are similar, based on registering a profile (generally for free) and on the possibility of adding contacts, inviting them to participate by selecting them from those who are already part of it, both for professional scopes such as in LinkedIn (Davis et al., 2020), and for personal purposes such as in Facebook, Instagram, Twitter, WhatsApp (Waterloo et al., 2018). An interesting factor for the marketers should be recognized into the ability of the virtual communities to act as an amplifier, through word-of-mouth news, trends and styles, thus allowing the development of different forms of viral marketing (Huang et al., 2019). Thus, today social media offers companies the opportunity to create web pages for marketing purposes and to communicated with their consumers (Colella et al., 2021; Jahn et al., 2012). Accordingly, social media marketing strategies consolidated its importance in the luxury sector too (Okonkwo, 2009). Regarding luxury consumers' motivations to use social media, Jahn et al. (2012) identify three main motives in terms of keep in touch and interacting with other consumers and with companies (Essamri et al., 2019; Kim \& Ko, 2012); the acquisition, distribution, and co-creation of functional or hedonistic content (Hagtveded \& Patrick, 2009; Phan et al., 2011; Vigneron \& Johnson, 2004); and finally self-presentation, which is linked to the social context and personal identity (Jahn et al., 2012). Therefore, among the main motivations that push consumers of luxury products towards the use of social media is self-presentation, which is based on its dimension of visibility of luxury (Jahn et al., 2012). In this context, the studies specified what efforts social media marketing activities have been successfully implemented in the context of luxury (Colella et al., 2021; Kim \& Ko, 2012; Godey et al., 2016). To illustrate, in order to positively influence consumers' luxury brands and products perception, in defining the best social media marketing strategy it is necessary consider five important to consider some fundamentals factors such as personalization, trend, positive WOM, interactions and thus communication with the target consumers (Godey et al., 2016; Kim \& Ko, 2012). According to Phan et al. (2011), to develop an efficient marketing strategy aimed at improving consumers' perception of their products, luxury brands need to have a clear understanding of the concept of social media marketing potentiality and usable tools, e.g., social media posts and picture to communicate and interact with their consumers (Chu et al., 2013). A significant aspect that emerged from these studies is the level of interactivity that luxury brands have acquired in recent years (Colella et al., 2021), with particular regard to the interactivity that consumers have in the various decision-making processes in the purchase of luxury products. Kim and Lee (2019), argue that in the context of luxury consumption, the interaction involves the reproduction of those consumers who share, disseminate and defend their ideas, values, and experiences and who support brands and products (Kim et al., 2012). The disruptive process of digitization of the communication systems of companies plays an important role in which it needs to increase one's skills in the analysis of the relationship between luxury and consumers on the web (Amatulli et al., 2017). According to Okonkwo (2009), through social media, consumers often have the perception of being in full control of their choices, generating a particular form of apprehension on the part of the luxury brand (Godey et al., 2016). Therefore, modern luxury consumers are gradually turning their attention to social media platforms (Colella et al., 2021; Martín-Consuegra et al., 2019), and, according to Yu et al. (2017), activities carried out on social media platforms tend to increase consumer experience, brand engagement, interactivity, and brand loyalty, making companies' communication more accessible. By extension, such social media marketing strategies for luxury brands are becoming recurrent, especially to drive communication campaigns and advertising (see Colella et al., 2019 for a review). As a marketing strategy, several luxury brands are increasingly investing their marketing efforts towards digital communication, becoming pioneers in how they use various social media platforms (Heine \& Berghaus, 2014), as for Burberry (as shown by Phan et al., 2011). Importantly, the social media advertising that disseminates messages and information about luxury brands tends to promote the purchase of luxury brands (Chu et al., 2019) and consumers-generated content are one of the most effective ways for interact with them via social media (Colella et al., 2021; Hasbullah et al., 2020). These contents shared via 
social media may have more influence than other sources, mainly because it is disseminated from a reliable source of information accumulated from a consumer's personal network (Castronovo \& Huang, 2012). Based on this assumption, and on the luxury dicothomy scrutinized above, we hypothesize that:

H1. The sustainable luxury product focus (Internalized Vs. Externalized) positively influences consumers' intention to buy sustainable luxury products.

\subsection{Sustainable Luxury Consumption and Luxury Product Quality}

Sustainable consumption is defined as "the consumption that supports the ability of current and future generations to meet their material and other needs, without causing irreversible damage to the environment or loss of function in natural systems" (Oxford Commission on Sustainable Consumption, 2000). Interestingly, consumers are becoming to be more attentive to sustainable consumption and their buying behaviour, in an attempt to alleviate the impact of their purchases on the environment (e.g., in Amatulli et al., 2021). By leveraging on such consumers' increasing concern for the impact of their consumption choices, most luxury brands have come to act in sustaining such forms of consumption (e.g., Athwal et al., 2019). However, Kapferer (2010) noted that luxury and sustainability are convergent because both focus on rarity, and high quality, due to consumers' growing interest in sustainability issues, scholarly research has been engaging in a very lively debate on sustainable luxury branding and consumption by demonstrating that sustainable luxury consumption has not a negative meaning (e.g., in Amatulli et al., 2017, 2021), but can maintain the same product quality standards while safeguarding the environment (Athwal et al., 2019). Despite the current increased consumers' attention of environmental issues and sustainable consumption, consumers who are concerned about the environment still remain uncertain about sustainable purchases due to the perceived lack of complete quality of some products (e.g., in Peattie \& Charter, 2003).Indeed, if on the one hand, they prefer to buy green products because they do not damage or negatively affect the external environment, stimulating emotions such as "feeling proud" and an active part of environmental protection, on the other, they are wary of the higher costs of green products or perceived lower quality (D'Souza et al., 2017). Furthermore, researchers showed that the quality of products has a direct effect on the performance while also being closely linked with the satisfaction of the customers, their loyalty, and the intentions of repurchasing (Asgharian et al., 2012; Eskildsen et al., 2004). Accordingly, previous studies (e.g., D’Souza et al., 2017; Jaiswal \& Kant, 2018) has shown that sustainable product quality moderates neither the relationship between attitude towards environmental issues and purchasing behavior, nor the relationship between information and purchasing behavior. Thus, marketers and managers should focus on the transparency and credibility of sustainable products and consumption, in the attempt to enable consumers to better understand the characteristics and usefulness of their products through appropriate communication focuses, by leveraging on the possible effects deriving from green product consumptions (Suki, 2016). Thus, we suggest that:

H2. Consumers' perceived product quality mediate the relationship between sustainable luxury product communication focus (Internalized Vs. Externalized), and their intention to buy.

To clarify, our conceptual framework is provided in the figure below (Figure 1).

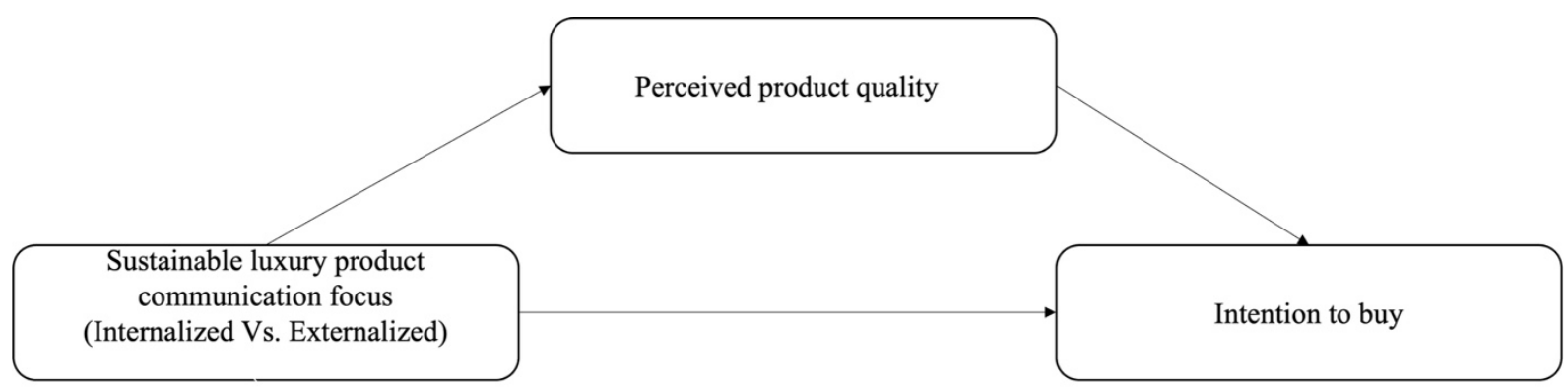

Figure 1. The proposed conceptual framework: The mediating role of consumers' perceived product quality

\section{Methdology}

With the aim of empirically testing our hypothesis, this study uses a quantitative approach. Thus, we developed the questionnaire for data collection. The questionnaire was created on the Qualtrics platform and was 
distributed to a pool of online participants via Amazon MTurk (Aguinis et al., 2020). Once the distribution of the questionnaire was completed and 160 observations were collected, incomplete observations were eliminated. The final sample consisted of 130 questionnaires, of which 75 were female (57.7\%) and 55 were male (42.3\%). Moreover, $73 \%$ of the sample declared to have a bachelor's degree or a higher academic qualification. At the beginning of the questionnaire, we randomly assigned participants to a two-cell (sustainable luxury product communication focus: internalized vs. externalized luxury) between-subjects experiment design. Participants were randomly presented with two versions of a communication message about a new pair of sustainable sunglasses collection in two scenarios resulting from the manipulation of the independent variable, that is, the sustainable luxury product communication focus on a social media platform (Instagram). Among the participants 65 of them have been exposed to the internalized luxury condition, and 65 to the externalized luxury one. In order to avoid a particular influence of brand familiarity on consumers' evaluations we used a fictitious brand. In both scenarios, the post published on the Instagram page first communicated that the product was produced with eco-sustainable materials by incorporating in its advertising a communication message that focused on the motivations related to luxury consumption. In the internalized luxury condition, a communication message was emphasized that accentuated the consumer's personal style, while in the externalized luxury condition, a communication message emphasized that accentuated the status of the consumer (e.g., "Let's get your style" for the internalized stimuli, and "Let's show off your status" for the externalized one). After to being exposed to the manipulation, participants were asked to rate the constructs from the literature. Study variables were measured with pretested scales from previous studies. First, the perceived quality of the product was measured using an item (rated on a bipolar scale; 1 = "overall poor quality"; 7 = "overall excellent quality") drawn from Dekhili et al. (2019). Subsequently, we measured consumers' intention to buy the sustainable product using the three-item scale developed by Bian and Forsythe, 2012 (e.g., "It is very likely I would buy the sustainable luxury brand"; "I would be interested in buying the sustainable luxury brand"; "I would like to own the sustainable luxury brand"; $\alpha=.97)$, to which participants responded on a seven-point Likert scale $(1=$ strongly disagree, $7=$ strongly agree).

\section{Results and Discussion}

To test our hypothesis, we ran the simple mediation model (Model 4) by Hayes' (2017) of the PROCESS macro for SPSS. The mediation model included the sustainable luxury product communication focus on the social media platform (internalized luxury condition $=1$; externalized luxury condition $=-1$ ) as the dependent variable, consumers' intention to buy as an independent variable and the perceived product quality which acted as a mediator of the relationship between the independent variable and the dependent variable. First, we regressed the perceived product quality on the independent binary variable, and then we regressed consumers' intention to buy on the perceived quality and on the independent variable. Results showed a significant and positive effect (b $=.31, \mathrm{t}(130)=2.41, \mathrm{p}=.02)$ of the type of sustainable luxury product communication focus on consumers' perceived product quality. Furthermore, the perceived product quality had a positive and significant effect on consumers' intention to buy $(\mathrm{b}=0.93, \mathrm{t}(130)=12.78, \mathrm{p}=<.01)$. It is important to underline that the results revealed a non-significant direct effect $(b=-.14, n s)$ of the sustainable luxury product communication focus on the consumers' intention to buy, but a significant and positive indirect effect of the independent variable on the dependent one through perceived quality $(b=.29,95 \%$ CI: .06,.53) (see Figure 2 below).

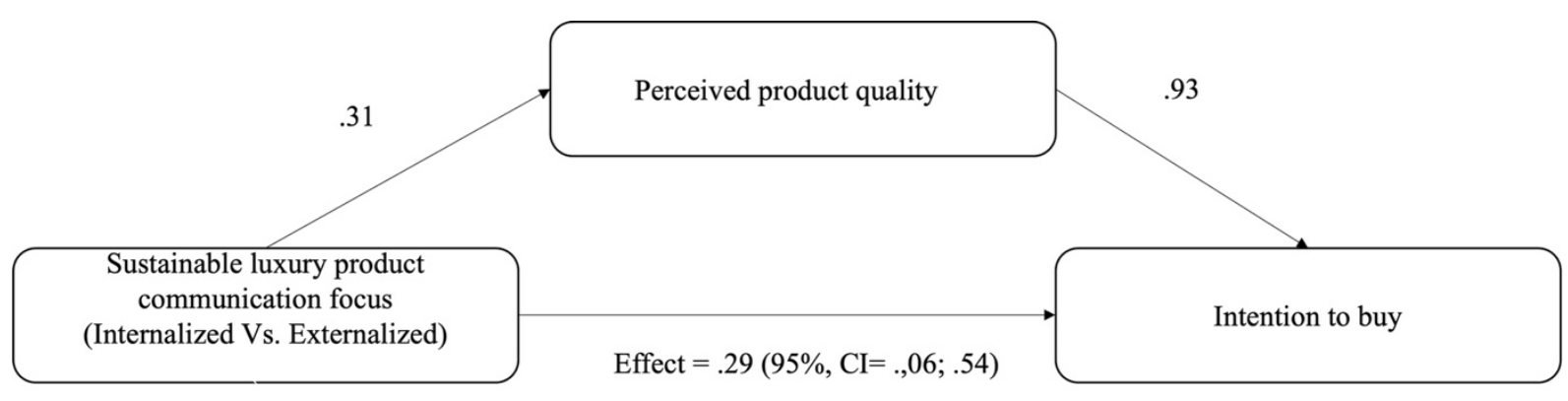

Figure 2. Results related to the simple mediaton model

Results demonstrate that consumers perceive a higher quality of sustainable luxury products when they are exposed to a communication message on the social media platform of a sustainable luxury brand that emphasizes 
an internalized (vs. externalized) luxury consumption approach. In turn, consumers' greater perception of product quality leads to a higher intention to buy. These results supported our hypothesis. Moreover, for greater clarity of results we dabbed a Confirmatory Factor Analysis (CFA) to the different constructs considered in the study, finding satisfactory factor loadings and acceptable data fit (Hu \& Bentler, 1999) (see Table 1).

Table 1. Confirmatory factor analysis for study

\begin{tabular}{ll}
\hline Variables and items & Standard. FL \\
\hline Perceived product quality & \\
This product has an adequate lifespan & 0.76 \\
Intention to buy & \\
It is very likely I would buy the sustainable luxury brand & 0.94 \\
I would be interested in buying the sustainable luxury brand & 0.94 \\
I would like to own the sustainable luxury brand & 0.96 \\
Fit statistics: & \\
$\chi^{2}$ & 3.73 \\
$\chi^{2} /$ df & $1.86^{*}$ \\
GFI & 0.99 \\
CFI & 0.99 \\
SRMR & 0.01 \\
RMSEA & 0.08 \\
\hline
\end{tabular}

Note. $N=130 ; F L=$ Factor Loading; $S E=$ Standard Error; df (degrees of freedom) $=2 ; * p=0.155$; all factor loadings are significant at the .001 level.

Although the results only point to an indirect effect of the sustainable luxury product communication focus on consumers' intention to buy (via perceived product quality), these findings offer support to our hypothesis by confirming that the perception of quality fully mediated the effect of the type of communication focus on consequent buying intentions.

\section{Conclusions and Future Research Directions}

\subsection{Overall Findings}

The purpose of this paper was aimed to investigate how the luxury product communication focus - in a social media research setting - may influence consumers' intention to buy, by shedding light on the mediator role of perceived product quality in influencing this relationship. Specifically, we exposed a sample of consumers to a communication message related to a sustainable luxury product, manipulating the communication focus (internalized vs. externalized), according to the definition of Amatulli and Guido (2011) which emphasizes an internalized (vs. externalized) approach to luxury consumption. Indeed, while internalized luxury refers to luxury consumption mainly driven by "internal" and ego-related motives, such as lifestyle and product quality, the externalized luxury refers to "external" luxury motives driven by consumers' status and price of the product. In this sense, consumers' perceived product could not be considered. Our results showed that higher perceived product quality denotes higher consumers' intention to buy, confirming that the type of attention to communication influences the perceived quality. Thus, the type of sustainable luxury product communication focus (internalized vs. externalized luxury) influences the perceived product quality, which in turn increases the consumers' intention to buy those products.

\subsection{Theoretical Implications and Contributions}

Theoretically, this study offers four main contributions to the literature. First, our results may advance knowledge of luxury research and practices by shedding light on how the sustainable luxury product communication focus influence consumers' intention to buy. Indeed, the results underline that sustainable luxury product communication focus can lead to higher green consumption values when the reasons for luxury consumption are mainly internalized (vs. externalized). Although several studies on luxury have focused on this dichotomy (Amatulli \& Guido, 2012; Eastman \& Eastman, 2015; Guido et al., 2020; O'Cass \& McEwen, 2004), to the best of our knowledge, no studies previously focused on emphasizing communication focused on the motivational status of luxury consumers and how it may influence their buying intentions. Second, we extend the literature on sustainable consumption by increasing knowledge on how luxury products are becoming adaptable with sustainable concepts and pro-environmental behaviors. Furthermore, our results show that the perceived product quality can increase sustainable luxury consumption. Third, this research contributes to the social media 
marketing literature by revealing how social media can be useful in proposing luxury communications by acting on different communication focuses to stimulate sustainable consumption behaviors. Indeed, the results show how social media platforms can become primary tools for communicating the sustainability of luxury brands and products. Particularly, through the sustainable luxury product communication focus on published posts (e.g., on social media), our results show how consumers with more intrinsic motivations for luxury consumption increase their intention to buy luxury products, especially for those consumers characterized by an internalized approach to luxury. Lastly, this research contributes to the literature on luxury product values, confirming that consumers' perceived product quality represents an important value for luxury consumers with extremely intrinsic values (Dubois et al., 2001) and, secondly, showing that this value can also be transmitted through a communication focused on social media platforms.

\subsection{Managerial Implications}

By considering our results, several marketing implications may derive. Firstly, luxury marketers and managers' efforts should be directed both to emphasize the communication focus and increase the quality perception of proposed products in consumers' minds, expecially regarding sustainable luxury products. Indeed, due to the complex combination of sustainability and luxury, consumers do not always perceive sustainable luxury products as being of high quality. Thus, communication campaigns should be directed to emphasize the quality hidden in sustainable luxury products too, making recognizable their unicity as a "perfect combination" able to bring closed two concepts traditionally far, such as luxury and sustainability, confirming the effectiveness of luxury brands' messages (Sestino et al., 2021). Communicating product quality characteristic may be a winning strategy to reach those consumers luxury consumers, both typically reluctant toward such new luxury brand propositions, and led by externalized motivations in luxury consumption (Amatulli \& Guido, 2011). Moreover, according to the luxury dichotomy (Amatulli \& Guido, 2012), our findings may suggest how to reach consumers both led by luxury "internal" consumption motives, and "external" consumption ones. Indeed, while consumers characterized by "internalized" consumption motives typically seek lifestyle and product quality, the second one, is typically led by status satisfaction, and price. Accordingly, emphasizing sustainable luxury product characteristics may be useful both to satisfy those consumers looking for product quality in their consumption, and to incentivize those consumers looking for status, also in the attempt "to go green to be recognized" (Griskevicius et al., 2010). Furthermore, the results suggest that marketing and advertising activities on social networks should be more oriented towards responsible communication, emphasizing the advantages deriving from the consumption of sustainable luxury products in terms of improving the environmental impact, without however the intrinsic quality. Therefore, effective marketing strategies induce consumers to buy sustainable luxury products, and adopt respectful behaviors toward the environment, by leveraging on related psychological benefits, for example also by placing images that evoke nature, thus forming a positive image in consumers' mind, building a sustainable consumption image as better than traditional consumption (Peattie \& Crane, 2003, 2005).

\subsection{Limitations and Future Research}

Despite the usefulness of our results, however, we acknowledge that this study has some limitations too. Notwithstanding the analyzed sample is representative, the results scalability may be limited. Moreover, some fundamentals variables characterizing luxury consumptions have been neglected and may be useful in deeply investigate consumers' behaviour. Thus, future studies could strengthen our study by shedding light on the possible role of some important luxury consumption-related characteristics (Colella et al., 2019) in terms of authenticity, quality, premium price, resonance, visibility, and prestige.

\section{References}

Aguinis, H., Villamor, I., \& Ramani, R. S. (2020). MTurk Research: Review and Recommendations. Journal of Management, 47(4), 823-837. https://doi.org/10.1177/0149206320969787

Amatulli, C., De Angelis, M., Costabile, M., \& Guido, G., (2017). Sustainable luxury brands: Evidence from research and implications for managers. Springer. https://doi.org/10.1057/978-1-137-60159-9

Amatulli, C., De Angelis, M., \& Stoppani, A. (2021). The appeal of sustainability in luxury hospitality: An investigation on the role of perceived integrity. Tourism Management, 83, 104228. https://doi.org/10.1016/j.tourman.2020.104228

Amatulli, C., \& Guido, G. (2011). Determinants of purchasing intention for fashion luxury goods in the Italian market: A laddering approach. Journal of Fashion Marketing and Management, 15(1), 123-136. https://doi.org/10.1108/13612021111112386 
Amatulli, C., \& Guido, G. (2012). Externalised vs. internalised consumption of luxury goods: propositions and implications for luxury retail marketing. The International Review of Retail, Distribution and Consumer Research, 22(2), 189-207. https://doi.org/10.1080/09593969.2011.652647

Asgharian, R., Salehi, M., Saleki, Z. S., Hojabri, R., \& Nikkheslat, M. (2012). Green product quality, green customer satisfaction, and green customer loyalty. International Journal of Research in Management \& Technology, 2(5), 2249-9563.

Athwal, N., Wells, V. K., Carrigan, M., \& Henninger, C. E. (2019). Sustainable luxury marketing: A synthesis and research agenda. International Journal of Management Reviews, 21(4), 405-426. https://doi.org/10.1111/ijmr.12195

Atwal, G., \& Williams, A. (2017). Luxury brand marketing-the experience is everything! In Advances in luxury brand management (pp. 43-57). Palgrave Macmillan, Cham. https://doi.org/10.1007/978-3-319-51127-6_3

Belk, R. W. (1985). Materialism: Trait aspects of living in a material world. Journal of Consumer Research, 12(3), 265-280. https://doi.org/10.1086/208515

Belk, R. W. (1999). Leaping luxuries and transitional consumers. Marketing Issues in Transitional Economies, 39-54. Springer, Boston, MA. https://doi.org/10.1007/978-1-4615-5009-9_2

Bian, Q., \& Forsythe, S. (2012). Purchase intention for luxury brands: A cross cultural comparison. Journal of Business Research, 65, 1443-1451. https://doi.org/10.1016/j.jbusres.2011.10.010

Castronovo, C., \& Huang, L. (2012). Social media in an alternative marketing communication model. Journal of Marketing Development and Competitiveness, 6(1), 117-134.

Chaudhuri, H., Mazumdar, S., \& Ghoshal, A. (2011). Conspicuous consumption orientation: Conceptualisation, scale development and validation. Journal of Consumer Behaviour, 10(4), 216-224. https://doi.org/10.1002/cb.364

Chu, S. C., Kamal, S., \& Kim, Y. (2019). Re-examining of consumers' responses toward social media advertising and purchase intention toward luxury products from 2013 to 2018: A retrospective commentary. Journal of Global Fashion Marketing, 10(1), 81-92. https://doi.org/10.1080/20932685.2018.1550008

Colella, G., Amatulli, C., \& Martinez-Ruiz, M. P. (2019). Social Media Marketing and Luxury Consumption: A Literature Review. International Journal of Marketing Studies, 11(4), 30-52. https://doi.org/10.5539/ijms.v11n4p30

Colella, G., Amatulli, C., \& Martinez-Ruiz, M. P. (2021). Social media interactions and brand luxuriousness: The role of materialism. Journal of Consumer Marketing, 38(4), 434-444. https://doi.org/10.1108/JCM-02-2020-3650

D'Souza, C., Taghian, M., \& Khosla, R. (2007). Examination of environmental beliefs and its impact on the influence of price, quality and demographic characteristics with respect to green purchase intention. Journal of Targeting, Measurement and Analysis for Marketing, 15(2), 69-78. https://doi.org/10.1057/palgrave.jt.5750039

Davis, J., Wolff, H. G., Forret, M. L., \& Sullivan, S. E. (2020). Networking via LinkedIn: An examination of usage and career benefits. Journal of Vocational Behavior, 118, 103396. https://doi.org/10.1016/j.jvb.2020.103396

De Angelis, M., Amatulli, C., \& Zaretti, M. (2020). The Artification of Luxury: How Art Can Affect Perceived Durability and Purchase Intention of Luxury Products. In Sustainable Luxury and Craftsmanship (pp. 61-84). Springer, Singapore. https://doi.org/10.1007/978-981-15-3769-1_4

Dekhili, S., Achabou, M. A., \& Alharbi, F. (2019). Could sustainability improve the promotion of luxury products? European Business Review, 31(3), 488-511. https://doi.org/10.1108/EBR-04-2018-0083

Dubois, B., Laurent, G. \& Czellar, S. (2001). Consumer rapport to luxury: Analyzing complex and ambivalent attitudes. Working Paper Series: CR 736/2001, Paris.

Dubois, D., Jung, S., \& Ordabayeva, N. (2020). The Psychology of Luxury Consumption. Current Opinion in Psychology, 39, 82-87. https://doi.org/10.1016/j.copsyc.2020.07.011

Eastman, J. K., \& Eastman, K. L. (2015). Conceptualizing a model of status consumption theory: an exploration of the antecedents and consequences of the motivation to consume for status. Marketing Management Journal, 25(1), 1-15. 
Eskildsen, J., Kristensen, K., JØrn Juhl, H., \& Østergaard, P. (2004). The drivers of customer satisfaction and loyalty. The case of Denmark 2000-2002. Total Quality Management \& Business Excellence, 15(5-6), 859-868. https://doi.org/10.1080/14783360410001680297

Essamri, A., McKechnie, S., \& Winklhofer, H. (2019). Co-creating corporate brand identity with online brand communities: A managerial perspective. Journal of Business Research, 96, 366-375. https://doi.org/10.1016/j.jbusres.2018.07.015

Gallaugher, J., \& Ransbotham, S. (2010). Social media and customer dialog management at starbucks. MIS Quarterly Executive, 9(4), 197-212.

Godey, B., Manthiou, A., Pederzoli, D., Rokka, J., Aiello, G., Donvito, R., \& Singh, R. (2016). Social media marketing efforts of luxury brands: Influence on brand equity and consumer behavior. Journal of Business Research, 69(12), 5833-5841. https://doi.org/10.1016/j.jbusres.2016.04.181

Gretry, A., Horváth, C., Belei, N., \& van Riel, A. C. (2017). Don’t pretend to be my friend! When an informal brand communication style backfires on social media. Journal of Business Research, 74, 77-89. https://doi.org/10.1016/j.jbusres.2017.01.012

Griskevicius, V., Tybur, J. M., \& Van den Bergh, B. (2010). Going green to be seen: Status, reputation, and conspicuous conservation. Journal of Personality and Social Psychology, 98(3), 392. https://doi.org/10.1037/a0017346

Guido, G., Amatulli, C., Peluso, A. M., De Matteis, C., Piper, L., \& Pino, G. (2020). Measuring internalized versus externalized luxury consumption motivations and consumers' segmentation. Italian Journal of Marketing, 1-23. https://doi.org/10.1007/s43039-020-00002-9

Hagtveded, H., \& Patrick, V. (2009). The broad embrace of luxury: Hedonic potential as a driver of brand extendibility. Journal of Consumer Psychology, 19(4), 608-619. https://doi.org/10.1016/j.jcps.2009.05.007

Han, Y. J., Nunes, J. C., \& Dreze, X. (2010). Signaling status with luxury goods: The role of brand prominence. Journal of Marketing, 74(4), 15-30. https://doi.org/10.1509/jmkg.74.4.015

Hasbullah, N. N., Sulaiman, Z., \& Mas'od, A. (2020). User-Generated Content Sources: The Use of Social Media In Motivating Sustainable Luxury Fashion Consumptions. International Journal of Scientific and Technology Research, 9(3), 5208-5214.

Heine, K., \& Berghaus, B. (2014). Luxury goes digital: how to tackle the digital luxury brand-consumer touchpoints. Journal of Global Fashion Marketing, 5(3), 223-234. https://doi.org/10.1080/20932685.2014.907606

Hu, L. T., \& Bentler, P. M. (1999). Cutoff criteria for fit indexes in covariance structure analysis: Conventional criteria versus new alternatives. Structural Equation Modeling: A Multidisciplinary Journal, 6(1), 1-55. https://doi.org/10.1080/10705519909540118

Huang, H., Shen, H., Meng, Z., Chang, H., \& He, H. (2019). Community-based influence maximization for viral marketing. Applied Intelligence, 49(6), 2137-2150. https://doi.org/10.1007/s10489-018-1387-8

Hudders, L., Pandelaere, M., \& Vyncke, P. (2013). Consumer meaning making: The meaning of luxury brands in a democratised luxury world. International Journal of Market Research, 55(3), 391-412. https://doi.org/10.2501/IJMR-2013-036

Jahn, B., Kunz, W., \& Meyer, A. (2012). The role of social media for luxury brands-Motives for consumer engagement and opportunities for business. Identitätsbasierte Luxusmarkenführung, 221-236. Springer Gabler, Wiesbaden. https://doi.org/10.1007/978-3-8349-4060-5_14

Jaiswal, D., \& Kant, R. (2018). Green purchasing behaviour: A conceptual framework and empirical investigation of Indian consumers. Journal of Retailing and Consumer Services, 41, 60-69. https://doi.org/10.1016/j.jretconser.2017.11.008

Jiang, Y., Li, Z., \& Cutter, S. L. (2019). Social network, activity space, sentiment, and evacuation: what can social media tell us? Annals of the American Association of Geographers, 109(6), 1795-1810. https://doi.org/10.1080/24694452.2019.1592660

Johnson, C. M., Tariq, A., \& Baker, T. L. (2018). From Gucci to green bags: Conspicuous consumption as a signal for pro-social behavior. Journal of Marketing Theory and Practice, 26(4), 339-356. https://doi.org/10.1080/10696679.2018.1487769 
Kadam, A., \& Deshmukh, R. (2019). Retrieved April 1, 2021, from https://www.alliedmarketresearch.com/luxury-travel-market

Kapferer, J. N. (1997). Managing luxury brands. Journal of Brand Management, 4(4), 251-260. https://doi.org/10.1057/bm.1997.4

Kapferer, J. N. (2010). All that glitters is not green: The challenge of sustainable luxury. European Business Review, 2, 40-45.

Kaplan, A. M., \& Haenlein, M. (2010). Users of the world, unite! The challenges and opportunities of social media. Business Horizons, 53(1), 59-68. https://doi.org/10.1016/j.bushor.2009.09.003

Keller, K. L. (2009). Managing the growth trade-off: Challenges and opportunities in luxury branding. Journal of Brand Management, 16(5-6), 290-301. https://doi.org/10.1057/bm.2008.47

Kim, A. J. Y., \& Ko, E. J. (2012). Do social media marketing activities enhance customer equity? An empirical study of luxury fashion brand. Journal of Business Research, 65(10), 1480-1486. https://doi.org/10.1016/j.jbusres.2011.10.014

Kim, J., \& Lee, K. H. (2019). Influence of integration on interactivity in social media luxury brand communities. Journal of Business Research, 99, 422-429. https://doi.org/10.1016/j.jbusres.2017.10.001

Kim, J., Spielmann, N., \& McMillan, S. J. (2012). Experience effects on interactivity: Functions, processes, and perceptions. Journal of Business Research, 65(11), 1523-1654. https://doi.org/10.1016/j.jbusres.2011.02.038

Ko, E., Costello, J. P., \& Taylor, C. R. (2019). What is a luxury brand? A new definition and review of the literature, Journal of Business Research, 99, 405-413. https://doi.org/10.1016/j.jbusres.2017.08.023

Kotler, P. (2011). Reinventing marketing to manage the environmental imperative. Journal of Marketing, 75(4), 132-135. https://doi.org/10.1509/jmkg.75.4.132

Kunz, J., May, S., \& Schmidt, H. J. (2020). Sustainable luxury: Current status and perspectives for future research. Business Research, 1-61. https://doi.org/10.1007/s40685-020-00111-3

Lee, S. H. N., Zhou, Y., Lo, C. K., \& Ha-Brookshire, J. (2018). Luxury fashion brands versus mass fashion brands: Data mining analysis of social media responses toward corporate sustainability. In Sustainability in luxury fashion business (pp. 51-73). Springer, Singapore. https://doi.org/10.1007/978-981-10-8878-0_4

Lunde, M. B. (2018). Sustainability in marketing: A systematic review unifying 20 years of theoretical and substantive contributions (1997-2016). AMS Review, 8(3-4), 85-110. https://doi.org/10.1007/s13162-018-0124-0

Maman Larraufie, A. F., \& Kourdoughli, A. (2014). The e-semiotics of luxury. Journal of Global Fashion Marketing, 5(3), 197-208. https://doi.org/10.1080/20932685.2014.906120

Martín-Consuegra, D., Díaz, E., Gómez, M., \& Molina, A. (2019). Examining consumer luxury brand-related behavior intentions in a social media context: The moderating role of hedonic and utilitarian motivations. Physiology \& Behavior, 200, 104-110. https://doi.org/10.1016/j.physbeh.2018.03.028

Mason, R. S. (2001). Conspicuous consumption: A literature review. European Journal of Marketing, 18(3), 26-39. https://doi.org/10.1108/EUM0000000004779

Mediakix. (2021). TikTok vs Instagram: Who wins social media in 2020. Retrieved from https://mediakix.com/blog/tiktok-vs-instagram-infographic/

Müller-Stewens, G., \& Berghaus, B. (2014). The market and business of luxury: an introduction. In B. Berghaus, G. Müller-Stewens \& S. Reinecke (Eds.), The management of luxury. A practitioner's handbook (pp. 3-25). Kogan Page, London.

Mundel, J., Huddleston, P., \& Vodermeier, M. (2017). An exploratory study of consumers' perceptions: What are affordable luxuries? Journal of Retailing and Consumer Services, 35, 68-75. https://doi.org/10.1016/j.jretconser.2016.12.004

Nia, A., \& Lynne Zaichkowsky, J. (2000). Do counterfeits devalue the ownership of luxury brands? Journal of Product \& Brand Management, 9(7), 485-497. https://doi.org/10.1108/10610420010351402

Nueno, J. L., \& Quelch, J. (1998). The mass marketing of luxury. Business Horizons, 41(6), 61-68. https://doi.org/10.1016/S0007-6813(98)90023-4 
O'Cass, A., \& McEwen, H., (2004). Exploring consumer status and conspicuous consumption. Journal of Consumer Behaviour: An International Research Review, 4(1), 25-39. https://doi.org/10.1002/cb.155

Obar, J. A., \& Wildman, S. (2015). Social media definition and the governance challenge: An introduction to the special issue. Telecommunications Policy, 39(9), 745-750. https://doi.org/10.1016/j.telpol.2015.07.014

Okonkwo, U. (2007). Luxury Fashion Branding. Palgrave Macmillan, Londra. https://doi.org/10.1057/9780230590885

Okonkwo, U. (2009). Sustaining the luxury brand on the Internet. Journal of Brand Management, 16(5-6), 302-310. https://doi.org/10.1057/bm.2009.2

Oxford Commission on Sustainable Consumption. (2000). Report on the Second Session of the Oxford Commission on Sustainable Consumption. OCSC 2.8, Oxford: Oxford Centre for the Environment, Ethics and Society.

Pantano, E., Passavanti, R., Priporas, C.-V., \& Verteramo, S. (2018). To what extent luxury retailing can be smart? Journal of Retailing and Consumer Services, 43, 90-100. https://doi.org/10.1016/j.jretconser.2018.03.012

Park, H., \& Kim, Y. K. (2016). Proactive versus reactive apparel brands in sustainability: Influences on brand loyalty. Journal of Retailing and Consumer Services, 29, 114-122. https://doi.org/10.1016/j.jretconser.2015.11.013

Peattie, K., \& Charter, M. (2003). Green Marketing. In M. Baker (Ed.), The Marketing Book. Butterworth-Heinemann, Burlington.

Peattie, K., \& Crane, A. (2005). Green marketing: legend, myth, farce or prophesy? Qualitative Market Tesearch: An International Journal, 8(4). https://doi.org/10.1108/13522750510619733

Reilly, A., \& Weirup, A. (2012). Sustainability initiatives, social media activity, and organizational culture: An exploratory study. Journal of Sustainability and Green Business, 1(1), 1-15.

Reilly, A. H., \& Hynan, K. A. (2014). Corporate communication, sustainability, and social media: It's not easy (really) being green. Business Horizons, 57(6), 747-758. https://doi.org/10.1016/j.bushor.2014.07.008

Phan, M., Thomas, R., \& Heine, K. (2011). Social media and luxury brand management: The case of Burberry. Journal of Global Fashion Marketing, 2(4), 213-222. https://doi.org/10.1080/20932685.2011.10593099

Richins, M. L., \& Dawson, S. (1992). A consumer values orientation for materialism and its measurement: Scale development and validation. Journal of Consumer Research, 19(3), 303-316. https://doi.org/10.1086/209304

Roux, E. (1991). Comment se positionnent les marques de-luxe? Revue Française du Marketing, 132/133(2-3), $111-118$.

Ryan, R. M., \& Deci, E. L. (2000). Self-determination theory and the facilitation of intrinsic motivation, social development, and well-being. American Psychologist, 55(1), 68. https://doi.org/10.1037/0003-066X.55.1.68

Sestino, A., Amatulli, C., \& Angelis, M. D. (2021). Consumers' Attitudes Toward Sustainable Luxury Products: The Role of Perceived Uniqueness and Conspicuous Consumption Orientation. In Handloom Sustainability and Culture (pp. 267-279). Springer, Singapore. https://doi.org/10.1007/978-981-16-5967-6_12

Sestino, A., Amatulli, C., \& Guido, G. (2021). Consumers' innovativeness and conspicuous consumption orientation as predictors of environmentalism: an investigation in the context of smart mobility. Technology Analysis \& Strategic Management, 1-14. https://doi.org/10.1080/09537325.2021.2020752

Sestino, A., \& De Mauro, A. (2021). Leveraging Artificial Intelligence in Business: Implications, Applications and Methods. Technology Analysis \& Strategic Management, 1-14. https://doi.org/10.1080/09537325.2021.2020752

Shao, W., Grace, D., \& Ross, M. (2019). Consumer motivation and luxury consumption: Testing moderating effects. Journal of Retailing and Consumer Services, 46, 33-44. https://doi.org/10.1016/j.jretconser.2018.10.003

Sheth, J. N., Newman, B. I., \& Gross, B. L. (1991). Why we buy what we buy: A theory of consumption values. Journal of Business Research, 22, 159-170. https://doi.org/10.1016/0148-2963(91)90050-8

Suki, N. M. (2016). Green product purchase intention: impact of green brands, attitude, and knowledge. British Food Journal. 
Sung, Y., Choi, S. M., Ahn, H., \& Song, Y. A. (2015). Dimensions of luxury brand personality: Scale development and validation. Psychology \& Marketing, 32(1), 121-132. https://doi.org/10.1002/mar.20767

Truong, Y., \& McColl, R. (2011). Intrinsic motivations, self-esteem, and luxury goods consumption. Journal of Retailing and Consumer Services, 18(6), 555-561. https://doi.org/10.1016/j.jretconser.2011.08.004

Tsai, S. P. (2005). Impact of personal orientation on luxury-brand purchase value: An international investigation. International Journal of Market Research, 47(4), 427-452. https://doi.org/10.1177/147078530504700403

Tsai, W. H. S., \& Men, L. R. (2013). Motivations and antecedents of consumer engagement with brand pages on social networking sites. Journal of Interactive Advertising, 13(2), 76-87. https://doi.org/10.1080/15252019.2013.826549

Veblen, T. (1899). The Theory of the Leisure Class. New York, The MacMillan Company.

Vigneron, F., \& Johnson, L. W. (1999). Review and a conceptual framework of prestige-seeking consumer behaviour, Academy of Marketing Science Review, 99(1), 1-15.

Vigneron, F., \& Johnson, L. W. (2004). Measuring perceptions of brand luxury. Brand Management, 11(6), 484-506. https://doi.org/10.1057/palgrave.bm.2540194

Wagner, T. F., Baccarella, C. V., \& Voigt, K. I. (2017). Framing social media communication: Investigating the effects of brand post appeals on user interaction. European Management Journal, 35(5), 606-616. https://doi.org/10.1016/j.emj.2017.05.002

Waterloo, S. F., Baumgartner, S. E., Peter, J., \& Valkenburg, P. M. (2018). Norms of online expressions of emotion: Comparing Facebook, Twitter, Instagram, and WhatsApp. New Media \& Society, 20(5), 1813-1831. https://doi.org/10.1177/1461444817707349

Yu, U. J., Cho, E., \& Johnson, K. K. P. (2017). Effects of brand familiarity and brand loyalty on imagery elaboration in online apparel shopping. Journal Global Fashion Marketing, 8, 193-206. https://doi.org/10.1080/20932685.2017.1284603

\section{Copyrights}

Copyright for this article is retained by the author, with first publication rights granted to the journal.

This is an open-access article distributed under the terms and conditions of the Creative Commons Attribution license (http://creativecommons.org/licenses/by/4.0/). 